\title{
US Foreign Policy under President Obama and the Challenge of Pakistan
}

\author{
Steven Ekovich
}

\section{Introduction}

President Barack Obama issued his first National Security Strategy of the United States of America on May 26, 2010. The document is a statutory requirement by Congress, prepared periodically and published by the executive branch, which outlines the major national security concerns of the United States and how the administration plans to deal with them. There was a great deal of anticipation to see what the new president's first official presentation of national security would look like, and how it would differ from those issued by former president George W. Bush. On the very first page of the strategy there are only two countries mentioned - Afghanistan and Pakistan. But their mention at the top of the document is not really a place of pride, they are there as manifestations of America's central security concerns: "Going forward, there should be no doubt: the United States of America will continue to underwrite global security - through our commitments to allies, partners, and institutions; our focus on defeating al-Qa'ida and its affiliates in Afghanistan, Pakistan, and around the globe; and our determination to deter aggression and prevent the proliferation of the world's most dangerous weapons."(National Security Strategy of the United States 2010)

Slightly later on Pakistan is evoked, as well as Afghanistan, as the "frontline" in the fight against al-Qa'ida and the Taliban. This is not the first time both countries have been so characterized. In fact it is a term so frequently used that a new word has been invented in the English language to describe the troubled region: Afpak. Such a prominent place given to Afghanistan and Pakistan is not at all unexpected. When President Obama entered the Oval Office, he immediately set out to deliver on his most important campaign promise on foreign policy: to refocus on the war in Afghanistan. What he called the "war of necessity" even before being elected. He announced only two months into his presidency: "I want the American people to understand that we have a clear and focused goal: to disrupt, dismantle and defeat Al Qaeda in Pakistan and Afghanistan and to prevent their return to either country in the future. That's the goal that must be achieved. That is a cause that could not be more just."(The White House Blog, March 27, 2009).

\section{Obama's Most Challenging Foreign Policy Problem}

It is often noted these days that no nation is more critical to U.S foreign policy than Pakistan and it is often characterized as Washington's most solid ally in South Asia even though the relationship has had its ups and downs, and even serious downs ( Mary Ann Weaver, 2003) The crucial nature of the relationship is due to several factors. First of all, terrorists groups in Pakistan are seen as a direct threat to the security of the United States because they are regularly linked to attacks on U.S. soil. Secondly,

Steven Ekovich is an Associate Professor at the American University of Paris, ekovich@aup.fr 
Pakistan is considered an integral part of the American war effort in Afghanistan. As President Obama points out, Pakistan plays a vital part in Washington's new strategy for Afghanistan. The president has asserted that Afghanistan cannot be "solved" without "solving Pakistan," which for the White House implies working more effectively with Islamabad. As early as December 2008 President-elect Obama announced his policy in a television interview: "[W]hat I want to do is to create the kind of effective, strategic partnership with Pakistan that allows us, in concert, to assure that terrorists are not setting up safe havens in some of these border regions between Pakistan and Afghanistan."(See the December 7, 2008, "Meet the Press)

A third factor is that Pakistan is a very important element in regional stability. This is particularly the case in terms of the evolving U.S. relationship with India. And of course Pakistan is a nuclear power and there is the constant, nagging fear that Islamabad may not be able to control its nuclear weapons and that they could fall into the hands of groups hostile not only to the United States, but also the Government of Pakistan itself. A concurrent concern is that Pakistan in the past has not been able to prevent the proliferation of nuclear weapons technology to other, distant powers hostile to the United States such as North Korea and Libya. The concern remains even though Pakistan has in recent years taken a number of steps to increase international confidence in the security of its nuclear arsenal, in particular to avoid a repetition of the procurement network run by former Pakistani nuclear official A.Q. Khan. Nevertheless, U.S. officials have recently expressed confidence in the security of Pakistan's nuclear weapons, even though there is persistent unease because the American knowledge of Islamabad's arsenal remains too limited for complete comfort. (Kerr and Mary Beth Nikitin, 2010) The nuclear issue also embraces the balance of forces between Pakistan and India. The Obama administration seems to accept that a certain level of minimum deterrence between Pakistan and India may be justified. On the other hand Secretary of State Hillary Clinton expressed a certain anxiety just head of Indian Prime Minister Dr. Manmohan Singh's visit to Washington (to attend the Nuclear Security Summit). She declared that "The manner in which India and Pakistan have pursued atomic weapons has "upset the balance of nuclear deterrence," and went on to add that the U.S. was working hard with India and Pakistan in a bid to limit their number of nuclear stockpiles. (U.S. Department of State, April 2010)

There is also an American concern about the transfer of civilian nuclear technology to Pakistan. In May 2010 the White House announced that it was carefully reviewing China's plans to build two civilian nuclear reactors in Pakistan. Even though China had previously built two reactors there, Beijing's nuclear exports are now more constrained after having joined the Nuclear Suppliers Group in 2004 (a cartel of nuclear energy states that forbids exports to nations lacking strict safeguards by the International Atomic Energy Agency). There are lingering fears about the safety of nuclear material inthelslamic nation. Even so, leaders of China, India and Pakistan were in attendance at the major summit on nuclear weapons convened in Washington by President Barack Obama in April 2010 and pledged to work to preserve nuclear security and allay those fears. Only time will tell if this turns out to be a success. (Agence France Presse, May 11, 2010) 


\section{The New Face of U.S. Policy towards Pakistan}

The ways in which the current administration is addressing the underlying factors in the U.S. relationship with Pakistan has raised the question of the extent to which Obama's approach is different from his predecessor's. After nearly two years in office, it is now possible to engage in the first evaluations of Obama foreign policy. The very fact of the election of Barrack Obama was the first, positive impact on America's relations with the rest of the world. In general, the image of the United States changed for the better. And image is indeed important in diplomacy. This appears to be the central reason he was awarded the Nobel Peace Prize, even though the president has said he does not really deserve it. But in particular here, how has the Pakistani view of Obama and the United States changed? The Pakistanis viewed the new president with a touch of affection that had not been given to other new entrants into the Oval Office. Obama's mother had worked in Pakistan for five years (1987-1992) on a development project for the Asian Development Bank. When the president was a student he had Pakistani friends and even a Pakistani roommate when he lived in New York. It was through one of these friends that he visited Karachi for a few weeks in 1981. This first-hand experience has created what Obama calls his "personal bond" with Pakistan.( Alan Fisher, January 19, 2010)

How does President Barack Obama stand in Pakistani opinion today? According to the most recent Pew Global Attitudes Project poll (just published in June 2010) President Obama's personal support in Pakistan is a mere eight per cent. This is a decline in Obama's popularity since the day he took the oath of office, and is part of a general erosion of his standing in the Muslim world. By comparison, in 2008 President Bush's personal rating by Pakistanis was seven percent. According to a summary of the survey, "More than a year after Barack Obama's landmark speech in Cairo, where he laid out his vision to repair relations with the Muslim world, Muslims are growing weary and disillusioned with the U.S. president and his international policies." Obama's favorability ratings in all seven Muslim-majority countries surveyed dropped from 2009 to 2010. "Among Muslim publics -- except in Indonesia where Obama lived for several years as a child -- the modest levels of confidence and approval observed in 2009 have slipped markedly," the report reads. Anecdotal evidence supports the polls. While strolling the streets of Gujranwala, where Obama's mother often came, Aljazeera reporter Alan Fisher collected excoriating comments. One man told him "As far as Obama is concerned only the face has changed, the policies are the same... It's just a continuation of what Bush did." Or, from another inhabitant: I am a Muslim man, and he is against me."(Pew Global Attitudes Project, 2010)

When it comes to views of the United States in general, and not just its president, in 2010 only 17 percent of Pakistanis view America favorably and only 18 percent view the American people favorably. Just 19 percent of Pakistanis believe that the U.S. considers their interests. All of these results are lower than in most of the years when George W. Bush was president. Also, Pakistan is the only country in which a majority (58\%) favors Iran acquiring nuclear weapons. Elsewhere among largely Muslim nations, public opinion on balance opposes a nuclear-armed Iran. In 2010 a large majority of Pakistanis, 65 percent, stated that U.S. troops should be removed from Afghanistan. Only seven percent thought they should remain. These differences in American and 
Pakistani public attitudes could become a source of future friction between the two countries. (Pew Global Attitudes Project, 2010)

Obama's speeches have also been well received, especially his Cairo speech directed to the Muslim world. However, the gains for American diplomacy remain unclear. His approach to America's adversaries has also been open, even indulgent - too indulgent for his critics. He has made well-received gestures and his style of dealing with the world has been largely appreciated, especially in comparison with George W. Bush. It is clear that Barack Obama is very skilful at deploying symbols - which once again count in diplomacy. For example, one important shift is the abandonment of the terms "Islamic terrorism," or "Islamic extremism" -- in favor of the now officially certified term "violent extremism" so as not to equate any religion with terrorism. For the president's critics, however, refusing to make the connection with a radical form of Islam avoids the obvious and "continues the absurd and embarrassing refusal of the Obama administration to acknowledge who out there is trying to kill Americans and why." One's enemy, they claim, should be clearly defined.( Charles Krauthammer, July 2, 2010). But to be fair to George W. Bush, he also regularly emphasized that the United States was not at war with Islam. However, the Obama White House is no longer using the term "war" as in "War on Terror." The new White House team has put it aside so as not to dignify the violent actions of the Taliban and al-Qa'ida as a jihad, a holy war, but rather as condemnable criminal activity. ( Jones and Martin C. Libicki, 2008)

Still, the persistent criticism of Obama's foreign policy is that it has been too heavy in symbols, but rather light in real substance, in concrete policy changes. The most generous interpretation that can be made of the early going is that the president is redefining the far-reaching arc of American foreign policy and preparing the terrain for changes to come. It is true that Obama has a penchant, and a talented one, for seeing the big picture and trying to deal with its myriad components without focusing too much on single narrow dimensions in isolation. This is laudable. On the other hand, the criticism remains that in trying to move too much at the same time, and by relying too much simply on words, very little is advanced. The problem is that by engaging in too many efforts there will be dissipation and paralysis. This president is attacked for his domestic policy in approximately the same terms - trying to do too much too fast and ending up with very little while unsettling public opinion. This Obama approach is also viewed by critics as hubris.

But the question here is how does this general approach of President Obama relate to his dealings with Pakistan in particular? How is Obama's Pakistan policy different from that of previous presidents? What are the continuities and discontinuities?

\section{U.S. Interests and Pakistani Sensitivities}

During the presidential campaign, as early as a debate between candidates for the nomination of the Democratic Party in August 2007, the issue of Pakistan was raised. Candidate Obama said that if it were necessary to root out terrorists, he would send U.S. forces into Pakistan without the country's approval. Obama's presidential rivals blasted him for these remarks. In words he would use again in the campaign, Obama 
said that "If we have actionable intelligence on al Qaeda operatives, including [Osama] bin Laden, and President Musharraf cannot act, then we should. That's just common sense." It is important to point out that the other candidates for the Democratic nomination jumped on Obama for his remarks not because he was announcing a policy change, but because they maintained that some policies must be kept diplomatically discreet. Hilary Clinton castigated the young senator for naiveté: "You can think big, but remember, you shouldn't always say everything you think if you're running for president, because it has consequences around the world." Another candidate at the time, Senator Joe Biden (future vice President), jumped in later in the debate recalling that the strategy Obama imprudently announced was already U.S. policy. "Everyone's entitled to their own opinion, but not their own facts," Biden remonstrated. "It is already the policy of the United States --has been for four years -- that there's actionable intelligence, we would go into Pakistan." During the campaign, Senator Obama also supported the Bush policy of drone strikes in Pakistan. As president he has not only continued the policy, but has increased the number of strikes - so this cannot be seen as a drastic change in doctrine. (Presidential Debates, August 8, 2007)

As soon as Obama became President he also reiterated his previous assertions that the U.S. military would indeed pursue extremists within Pakistan's borders - but now added "after consulting with the Pakistani government." The realities of the exercise of power once again had modulated campaign rhetoric - and perhaps also a certain lack of experience. During a television appearance on CBS's very popular "Face the Nation" in March 2009 (in the second month of his presidency) Obama said that his policy was not ignoring American recognition of Pakistan's "sovereign government" -but the president affirmed that the United States needs to hold that government "more accountable." "This is going to be hard," he added. "I'm under no illusions." (CNN politics.com, March 29, 2009)

Recent reports in major American newspapers have revealed continuing evolution in the Obama policy of cross-border strikes into Pakistan. The formulation "consultations with the Pakistani government" has taken on significant nuances - perhaps connected to agreements between Washington and Islamabad that are not publicly known. At root is the terrible dilemma of balancing American urgency and a respect for Pakistani sovereignty after discovery of a high-value target, a conundrum that remains inherently difficult to resolve. If intelligence sources locate such a target, a pressing need will emerge to act quickly -without having to go through potentially time-consuming and perhaps contentious consultations with Islamabad. The Washington Post revealed in its May 29, 2010 edition that the CIA has the authority to designate and strike targets in Pakistan without case-by-case approval from the White House. But such unilateral strikes inside Pakistan may be carried out "only if solid intelligence were to surface on any of three high-value targets: al-Qaeda leaders Osama bin Laden and Ayman al-Zawahiri, or Taliban chief Mohammad Omar." In those cases, the military does not need approval from the very top. The article also reveals that the U.S. military is reviewing options for a unilateral strike in Pakistan in the event that a successful attack on American soil is traced to the country's tribal areas. These revised retaliatory options are being considered in the wake of investigations that have brought to light ties between the alleged Times Square bomber, Faisal Shahzad, and elements of the Pakistani Taliban. As Secretary of State Hillary Rodham Clinton said in a television interview after 
the Times Square attempt "if, heaven forbid, an attack like this that we can trace back to Pakistan were to have been successful, there would be very severe consequences." However, the possible new policy has been hedged in with provisos meant to bow as much as practical to Pakistani sensitivities. U.S. action would be contemplated only under extreme circumstances, such as a catastrophic attack, and would not include a "large, punitive response" but rather more measured blows against specific militant groups. This could include incursion into Pakistani territory of small teams of U.S. Special Operations teams. A senior American official is quoted as saying that such a reprisal raid should be careful not to destroy the relationships that have been built with the Pakistani military. President Obama dispatched his national security adviser, James L. Jones, and CIA Director Leon Panetta to Islamabad after the Times Square fiasco to deliver a similar message to President Zardari and General Kayani. (Greg Miller, 2010)

\section{War in the Shadows}

Another report (The New York Times of May 24, 2010) reveals that General Petraeus, the top American commander in the Middle East and now in charge of Afghanistan, has ordered a broad expansion of clandestine military activity in an effort to disrupt militant groups and counter threats in Iran, Saudi Arabia, Somalia and other countries in the region. It is quite reasonable to suppose that "other countries in the region" include Pakistan. In any case, it is no secret that this is already occurring. In 2004 Pentagon authorized offensive strikes in more than a dozen countries. Special Operations troops carried them out in Syria, Pakistan and Somalia. So, while the Bush administration had approved some clandestine military activities, the new order is intended to make such efforts more systematic and long-term. For most commentaries in the American media it is not clear if these incursions have been carried out with or without the approval (secret, tacit or open) of the Pakistani government - or parts of it. The article brings to light that the secret directive, entitled "Joint Unconventional Warfare Task Force Execute Order," authorizes the sending of American Special Operations troops to both friendly and hostile nations to gather intelligence and build ties with local forces. As presented in The New York Times, it appears that the goals of the general's directive are to build networks that could "penetrate, disrupt, defeat or destroy" Al Qaeda and other militant groups, as well as to "prepare the environment" for future attacks by American or local military forces. It is important to underline that the order does not, however, seem to authorize offensive strikes in any specific countries. (Mark Mazzetti, May 24, 2010). Nevertheless, the Obama administration has significantly increased the number of drone strikes on Pakistani Taliban targets in the border region. Under the Bush administration there were reportedly only five in 2007 and 36 in 2008. In Obama's first year these more than doubled to 83 and their frequency has not declined so far in 2010. (O'Hanlon and lan S. Livingston, 2010) So, many top American commanders, General Petraeus among them, are in favor of an expansive interpretation of the military's role around the world, arguing that troops need to operate beyond Iraq and Afghanistan to better fight militant groups. This is not out of line with President Obama's conception of foreign and defense policy as an integrated big picture that encompasses regional and international dimensions, as well as all elements of U.S. power and diplomacy.

On June 4, 2010, The Washington Post led a story on special operations forces by 
affirming "Beneath its commitment to soft-spoken diplomacy and beyond the combat zones of Afghanistan and Iraq, the Obama administration has significantly expanded a largely secret U.S. war against al-Qaeda and other radical groups, according to senior military and administration officials." (Karen DeYoung and Greg Jaffe, 2010) The president has asked for a 5.7 percent increase in the Special Operations budget for fiscal year 2011 , for a total of $\$ 6.3$ billion, plus an additional $\$ 3.5$ billion in 2010 contingency funding. The surge in special operations deployments is presented in the Post article as the darker side of the recently published National Security Strategy of the United States of America. As in the past, for example President Eisenhower's use of the CIA and its covert actions, such operations have the advantage of sheltering the White House's use of force from public view. (Stephen E. Ambrose and Douglas G. Brinkley, 1997) As it is put in the Washington Post, "For a Democratic president such as Obama, who is criticized from either side of the political spectrum for too much or too little aggression, the unacknowledged CIA drone attacks in Pakistan, along with unilateral U.S. raids in Somalia and joint operations in Yemen, provide politically useful tools." One of the ironies noted by the two authors of the article is that such rhetoric is not much different than Bush's pledge to "take the battle to the enemy ... . and confront the worst threats before they emerge." (Stephen E. Ambrose and Douglas G. Brinkley, 1997)

So in terms of American policy regarding incursions into Pakistan, there has not been a real fundamental change, only modifications that attempt to take into consideration the sensitivities of Islamabad, although the nuances in what appear to be the new approach may not seem apparent or satisfactory to many Pakistanis.

\section{Style or Substance?}

A possible change in Obama policy toward Pakistan straddles a fuzzy line between style and substance: increased high-level visits to Pakistan as part of a renewed "strategic dialogue." For those who find successes in Obama's approach to Pakistan cite this highlevel personal diplomacy of regular senior-level trips, part of what is labeled a "whole of government" approach to Pakistan. (Fareed Zakaria, March 12, 2010). These have included visits by National Security Advisor Jim Jones, Secretary of State Hillary Clinton, Chairman of the Joint Chiefs of Staff Admiral Mike Mullen, General David Petraeus and General Stanley McChrystal and a number of other senior Administration officials and Members of Congress. Of course one of the most important major changes on the diplomatic level is the creation of a Special Representative for Afghanistan and Pakistan, naming the experienced Ambassador Richard Holbrooke to the post. (Shuja Nawa, 2010) The goal of this high-visibility diplomacy is to reassure Islamabad of Washington's longterm commitment to both Pakistan and Afghanistan and that both countries will be partners and not merely instruments of U.S. policy. This ostensibly is intended to undermine a long-held perception "that Pakistanis were abandoned by the U.S. after the Soviets withdrew from Afghanistan," as Foreign Minister Shah Mehmood Qureshi remonstrated at the Council on Foreign Relations on October 7, 2009. (Laura Rozen, 2009)

So, any new strategic dialogue should ideally be sustained over a long run. In the past the American relationship with Pakistan has been punctuated by positive engagement during crises. For example, General Anthony C. Zinni, George W. Bush's envoy to the 
Middle East, in speaking of the deep and long-running antipathy between Pakistan and India has ruminated: "There's no understanding by either side of what the other's red lines are, and this is the most dangerous thing. We've [the United States] played a role three times now [helping to defuse very serious crises in 1990,1999, and 2002]

when there was a potential for war. But we always stepped in at the eleventh hour to avert a catastrophe. I really think this has got to change. We're the only country in the world that can bridge the two sides, that can open communication lines, and I think we must become engaged." (Weaver, 2010) As seen from the Obama White House, a sustained strategic dialogue must necessarily also aim at convincing the Pakistani military and intelligence services that they will have a voice in the future of Afghanistan without resorting to questionable intermediaries such as the Taliban. As General Zinni noted, such a dialogue needs to include moves to attenuate the rivalry and suspicion between India and Pakistan, a relationship of intense and intimate strife. Newsweek gives the analysis of a senior American administration official: "The driving force from the outset is that Pakistan needed to be part of the regional strategy. They need to be comfortable they're going to have an Afghanistan on the border that will be stable and not a threat to them. The internal criticism there was that Pakistan was viewed by the Americans as a mere launching pad. Also, we provided assurances that the [planned] 2011 withdrawal [from Afghanistan] doesn't mean we're leaving." (Michael Hirsh, 2010)

Of course persuading Islamabad to get on board has been made easier by the shocking behavior of the Taliban themselves. When they extended their reach almost to the capital and even shook the Pakistani state to its foundations, they turned public opinion against them by imposing a very harsh version of Islamic law backed up by outrageous violence - brutal, cruel and even sadistic. Or as characterized by Shirin R. Tahir-Kheli, who grew up in Peshawar and later served at the U.S. National Security Council in three Republican administrations, Pakistan must "face up to the reality that its very existence is being threatened by the extremists who have hijacked the religion that they claim to avow fidelity to - and have turned it in a monstrous, illegitimate, un-godly theater of the macabre." (Tahir-Kheli, 2009) For National Security Advisor General Jones this realization is already taking place, "There is great support among the population for what the Pakistani army has been doing. Kayani certainly sees that. More than ever before, they [the Pakistani Army] have a sense of purpose and backing of the people." According to one internal government survey cited to Newsweek, about three quarters of Pakistanis now consider the Taliban to be a threat, whereas the percentage was down in the low 30s during the years of autocrat Pervez Musharraf. (Michael Hirsh, 2010)

The diplomatic outcome for those who view the Obama administration favorably has been an unprecedented degree of cooperation from the once-hesitant government in Islamabad, and progress in bringing the Pakistan military and civilian government closer together. The results in the military sphere have seen a number of top Taliban commanders wanted by both governments either killed or arrested. As the author of the Newsweek article says: "The remaining Pakistani Taliban, who only a year ago enjoyed close to untouchable status, are now hunted men, including elements of the dangerous Haqqani Network in Waziristan. And the 'hammer and anvil' approach in Afghanistan-with NATO's Marja offensive serving as the hammer and Pakistani forces across the border acting 
been an unprecedented degree of cooperation from the once-hesitant government in Islamabad, and progress in bringing the Pakistan military and civilian government closer together. The results in the military sphere have seen a number of top Taliban commanders wanted by both governments either killed or arrested. As the author of the Newsweek article says: "The remaining Pakistani Taliban, who only a year ago enjoyed close to untouchable status, are now hunted men, including elements of the dangerous Haqqani Network in Waziristan. And the 'hammer and anvil' approach in Afghanistan-with NATO's Marja offensive serving as the hammer and Pakistani forces across the border acting as the anvil-may at last be working after nearly a decade of losing ground to encroaching Taliban, who had years to regroup from their safe haven in the mountainous tribal regions of Pakistan." (Michael Hirsh, 2010)

It is not very clear, however, if the Taliban leaders who have been targeted were sought out and killed as part of murky in-fighting between different factions allied with elements in both Afghanistan and Pakistan. Or as Lisa Curtis of The Heritage Foundation puts it, "given Pakistan's long track record of support for militant groups fighting in Afghanistan and India, it is too early to determine whether the most recent arrests signal a permanent reversal of past policies, or merely a tactical shift to demonstrate leverage in the region." (Lisa Curtis, 2010)

\section{Double Games}

Such suspicions can be easily raised in the light of recent news that Pakistan has not been pursing the Haqqani network, but rather supporting it. It is now evident that the embrace is aimed at influencing the military and political outcome in Afghanistan. (Jane Perlez, Eric Schmitt and Carlotta Gall, 2010) That this is not an isolated example of indirect and behind-the-scenes maneuvering by Islamabad is suggested by a report published in June 2010 by the London School of Economics and carried out by a Harvard University researcher. The study alleges a close, ongoing clandestine relationship between Afghan insurgents and Pakistan's Inter-Services Intelligence Directorate (the well-known ISI). (Matt Waldmann, 2010) The international prestige of both universities serves as a solid rampart against the vociferous denials of the Pakistani government. And it should be recalled that Harvard is the alma mater of president Obama. The publication of the report was covered on the front page of major Pakistani newspapers on June 14, 2010, along with the rebuttal of the government. (The Times, the News, Dawn, and the Nation. All on June 14, 2010) According to the study, "Pakistan appears to be playing a double game of astonishing magnitude" in Afghanistan. The author of the report conducted interviews from February-May 2010 with nine insurgent field commanders and one high-level Taliban intermediary. He also carried out interviews with ten former senior Taliban officials, twenty-two Afghan elders, tribal leaders, politicians and analysts; and thirteen foreign diplomats, experts and security officials. According to Taliban commanders the powerful role of the ISI is "as clear as the sun in the sky." (Matt Waldmann, 2010) However, for Pakistanis "The most stunning part of the study," reported the Pakistani daily Dawn, "was reserved for President Asif Ali Zardari, alleging he had assured captive senior Taliban leaders once that they were 'our people' and had his backing. He had apparently authorized some to be released from prison," the daily adds. (Matt Waldmann, 2010) The Zardari government dismissed the claims of the report as "malicious and 
baseless" and "absolutely spurious." (Dawn, June 14, 2010) As Professor Rajan Menon editorializes in the Los Angeles Times, even though Pakistani authorities have reacted angrily to a study, "the report affirms what has been common knowledge among academic specialists on Afghanistan and journalists with extensive experience in that country." (Rajan Menon, June 30, 2010).

The accusations are given added weight by the revelations of the former head of Afghanistan's intelligence agency, Amrullah Saleh, who resigned earlier in June - and who was highly appreciated by the Americans. "The ISI is part of the landscape of destruction in this country, no doubt," claims the Afghan most in the know about such things, "so it will be a waste of time to provide evidence of ISI involvement. "They are a part of it," he laments. The resignation of Saleh, as well as of the Afghan interior minister Hanif Atmar, is viewed as a concession by Kabul to Islamabad. "The two officials, favored by Washington, were viewed by Pakistan as major obstacles to its vision of hard-core Taliban fighters being part of an Afghanistan settlement, though the circumstances of their resignations did not suggest any connection to Pakistan." (Perlez, Schmitt and Gall, 2010)

It is too early to tell if the strategic dialogue offered by Obama will lead to an enduring exchange that will build and cement mutual confidence and respect. If indeed the conclusions of the LSE study are correct, then the new Pakistan - U.S. "strategic dialogue" must close the gap between words and actions in order to build real confidence. The Obama administration has challenged Islamabad in its lack of consistency in countering terrorism in the region. In an editorial in the Pakistani daily The News, U.S. Defense Secretary Robert Gates suggested that Pakistan could be doing more to fight terrorism, and that seeking to distinguish between different terrorist groups is counterproductive. U.S. Director of National Intelligence Admiral Dennis Blair elaborated on this criticism in testimony before Congress on February 2, 2010 by saying: "Pakistan's conviction that militant groups are strategically useful to counter India are hampering the fight against terrorism and helping al-Qaeda sustain its safe haven." (Lisa Curtis, 2010) Statements such as these by high-level officials may indicate that the patience of Obama's Washington with Islamabad is not unlimited. Nevertheless, the president is still sending ambiguous messages. On the one hand his CIA director Leon Panetta believes that negotiating with the top Taliban leadership is not possible, that the Taliban and their allies have "little motive to contemplate a power-sharing arrangement in Afghanistan" and that "that with regards to reconciliation, unless they're convinced that the United States is going to win and that they're going to be defeated, I think it's very difficult to proceed with reconciliation that's going to be meaningful." On the other hand the President says that "I think it's too early to tell. I think we have to view these efforts with skepticism but also with openness." (Scott Shane, 2010)

\section{Reorientation of Military Assistance}

An area where American policy has indeed changed in substance from Bush to Obama is in the nature of aid to Pakistan. Already George W. Bush had lifted previous sanctions that impeded aid to Islamabad after its military had crossed the nuclear threshold. The Bush White House re-opened the aid tap after 9/11 in return for Pakistan's efforts in the "war against terrorism." In the aftermath of the September 11 attacks in the United 
States, Musharraf undertook to restore his country's badly bruised reputation with the Americans, "confronting a growing array of critics, including skeptics in his own military constituency, who remember that Washington had walked away from Pakistan before, after the first U.S. - Afghan war." (Weaver, 2010) President Musharaff's change in Pakistan's strategic posture lead to an aid flow of around $\$ 12$ billion, primarily military and security related, in the years up to the start of Obama's entry into office. (Alan Kronstadt, 2009) As an added measure of support, Bush also designated Pakistan as a "major non-NATO ally" in June 2004, making it eligible, among other things, to purchase advanced American military technology.

President Obama has continued military aid to Pakistan, but has significantly reorienting it. Military assistance is increasingly being directed to counterinsurgency. This includes not only funding for such programs, but also providing training and the advanced technology most adapted to dealing with insurgency and terrorism. The new strategy involves practical efforts to advance American and Pakistani cooperation in the pursuit of terrorists. These include broadened sharing of intelligence, especially from drones and undisclosed new means of surveillance and eavesdropping technology employed by the U.S. National Security Agency. There has also been the creation of "fusion centers" in the troubled border regions of Pakistan, where intelligence operatives from both sides work together. The fusion centers are meant not only to uncover useful information about terrorist networks, but also to build up confidence between Pakistani and American intelligence and military officials. The fusion centers are presented as a way for both sides to keep an eye on each other, even though they may also be seen as an instrument to create Pakistani dependence on American high-tech intelligence collection. (Greg Miller, 2010) In short, as announced in the February 2010 Afghanistan and Pakistan Regional Stabilization Strategy: "Consistent with President Obama's commitment to strengthen Pakistan's capacity to target extremist groups that threaten our countries, we will sustain and focus our security assistance, with the aim of assisting Pakistan's efforts to eliminate safe-havens for terrorists that threaten Pakistan, Afghanistan, the region, and the world." (United States Department of State, February 2010)

There is some concern, however, that a troubling amount of military aid may be diverted to Kashmir. In an interview with the BBC, former President Musharaff admitted that he had indeed engaged in this type of diversion. BBC News (September 14, 2009) One of the conditions of the current military aid to Pakistan is that it will indeed be properly directed. Continuing military aid has been tied to Pakistani progress in the fight against militants. (U.S. Department of State, April 2010)

\section{Direct Aid to the People of Pakistan}

A much more important change in the aid going to Pakistan is the substantial increase directed toward civil society. Through the "Enhanced Partnership with Pakistan Act of 2009" (also known as the Kerry-Lugar bill), the U.S. will triple non-military aid to Pakistan to $\$ 1.5$ billion per year. The legislation was originally called the Biden-Lugar bill. When Obama was a Senator he also aimed at being a co-sponsor, so that he has said that it should then have properly been named the Biden-Lugar-Obama bill. (In the lower chamber Representative Howard Berman also played a substantial role in writing the bill) 
The package will support Pakistan's economic reform program and it seeks to strengthen its economic growth and stability. Assistance will be directed to agriculture, education, health, poverty alleviation, and energy. As examples, the new aid law authorizes the building of schools, roads, and hospitals; helping farmers improve their ability to raise crops and deliver them to the marketplace; stimulating new energy infrastructure; and strengthening Pakistan's democracy. But so as to demonstrate a long-term solid commitment, part of the new "strategic dialogue," the aid is to extend over 10 years. As President Obama put it in his speech at West Point Military Academy on December 1, 2009, "The Pakistani people must know that America will remain as a strong supporter of Pakistan's security and prosperity, long after the guns have fallen silent, so that the great potential of its people could be unleashed." (www.whitehouse.gov, 2010) It should be underlined that he U.S. is the single largest bilateral donor to the Pakistani people. But the new approach also encourages more people-to-people contacts_Americans and Pakistanis as well as mobilizing the Pakistani diaspora in the United States in the hopes of increasing its philanthropy and using its good will and knowledge. (Adil Najam, 2006)

So the purpose of the civilian aid is to put in place an aid program that is not just military, but broad in scope in order to bolster the democratic government led by President Zardari. A key campaign argument of Obama was that the US had made the mistake of "putting all our eggs in one basket" by backing General Musharraf. When Obama entered the White House he did not have to deal with this concern because President Musharraf was already gone_forced out of office under the threat of impeachment, after years of political protests by lawyers, civilians and other political parties in Pakistan. And even though George Bush had supported Musharaff in return for his help against extremism and the war in Afghanistan, at the end of the Pakistani president's term in office the Americans withdrew their support and manifested a preference for democratic elections that brought Asif Ali Zardari widower to power. The Bush team nevertheless was in favor of a "soft landing," an honorable exit for the former president. It should not be forgotten, though, that support for Musharraf was bi-partisan. Influential members of the Democratic Party also believed that the general was a necessary bulwark against the forces that were threatening to destabilize Pakistan.

A very important part of American aid is to help strengthen the relatively new democratic government led by President Zardari, particularly by strengthening civil institutions. This includes aid for education reform. The Pakistani government's funding for education has declined to become one of the lowest education budgets relative to GDP than any country on the globe, resulting in the collapse of what was once one of the developing world's better public school systems. This lack of adequate public education has led to the rise of Saudi-funded Islamic schools (madrasahs) many of which have served as recruiting grounds for terrorists. This is not to condemn all madrasahs, many of which do not incite violence but instaed serve useful educational purposes. There is a lively and scholarly debate about how widespread the most radical religious schools are and to what extent they turn out terrorists. Another goal is to get $50 \%$ of Pakistani children who are not presently in school an education that will improve Pakistan's chances to compete in the new, post-modern international economy. (Andrabi, Jishnu Das, Khwaja, and Zajonc, August 2006) 
There is some worry that a great part of the new infusion of aid will not really end up at the grassroots of civil society and positively touch the lives of ordinary Pakistanis. As a former member of the American National Security Council says, in Pakistan "the U.S. model for the dispensation of assistance is badly broken. After taking away $40 \%$ for American contractors and another large fraction for Pakistani contractors, miniscule amounts actually get delivered." (Kerry-Lugar letter, 2010) There is, of course, the usual concern that through corruption a sizeable part of the aid will end up in bank accounts outside of the country. For these reasons, the Chairman of the U.S. Senate Committee on Foreign Relations, Democrat John Kerry, and the ranking Republican member, Richard Lugar, sent a letter to the State Department on March 5, 2010 expressing concern of the Senators that the money must not be diverted and be spent exactly in the ways for which it was appropriated, and without waste. (Jeremy Page and Zaid Hussain, 2009) Not only do the Americans want to guarantee that the money actually goes to the people, they also do not want to be seen in the eyes of ordinary Pakistan's to be enriching their elites at their expense. Disclosure of the letter provoked an irritated reaction in Pakistan. Here once again it appeared that the Americans had little respect for Pakistani sovereignty because of what were viewed as "stringent terms." (Dawn (June 15, 2010) However not all Pakistani leaders disagreed with the Senators. For instance former Foreign Minister Riaz Khokar agreed with the letter, saying that he also was concerned about the possibility of aid to his country being misused, especially because "some people in this country have made corruption into a fine art." (Sebastian Abbott, 2010)

Besides Washington's conditions that military aid not be diverted and that assistance to civil society actually reach the people, there is a condition that has been in lace for many years that is troublesome for relations with Islamabad. This is the pipeline project from Iran. Richard Holbrooke warned Pakistan that the recently signed gas pipeline deal with Iran could run afoul of new sanctions on Iran being finalized in Congress. The U.S. has regularly discouraged countries from doing business with Iran because of its refusal to suspend uranium enrichment. But the announcement of the contract to build a pipeline from Iran has put the United States in a bind. On the one hand there are already Congressional sanctions in place on companies doing business with Iran in excess of $\$ 20$ million, and further sanctions are to come following the recent Security Council resolution against Iran. On the other hand, if the new orientation in American policy is to send more aid directly to Pakistani civil society in order to improve the lives of the people (including development aid to the energy sector), it is problematic to be seen impeding the amelioration of a severe energy crisis. Electricity shortages in Pakistan cause rolling blackouts that no only affect businesses, but cause irritating shutdowns and particularly intensify suffering when temperatures rise. And of course Pakistan is a vital partner Washington's fight against al-Qaida and the Taliban. (Jayshree Bajora, January 2009)

\section{An International Migraine?}

Pakistan contains everything "that gives you an international migraine," commented former U.S. Secretary of State Madeleine Albright at a recent meeting at the prestigious Council on Foreign Relations. The author who reports her wry remarks notes that "Albright echoes popular sentiment in Washington: With its nuclear weapons, terrorism, 
poverty, corruption, faltering economy, weak government, and critical geostrategic location, Pakistan is a top concern for the Obama administration." (Jayshree Bajora, January 2009) But as Frederick Kempe, the president of The Atlantic Council, puts it more prosaically, "Perhaps no bilateral relationship in the world matches that of the United States and Pakistan when it comes to its combustible combination of strategic importance and perilous instability." (Frederick Kempe, 2010) The goals that the United States and Pakistan share are not always easy to balance against the objectives that they do not share. While both are fighting terrorism, they see the struggle in different terms. Fundamentally the U.S. is looking for an honorable military exit out of a stabilized Afghanistan. Pakistan seeks to secure its own territory and interests while keeping a suspicious eye on India. An incomplete transition to democratic rule and a weak economy undermine Pakistani strategies. Washington would like to see a stable, democratic, prosperous Pakistan actively working to counter all forms of terrorism. President Obama is trying to get there, but the task is daunting - and not immune from collapse. Perhaps only a lyrical conclusion can summarize the relations between the two necessary allies. Professor Rifaat Hussain of Quaid-i-Azam University in Islamabad (who was previously posted at the Embassy of Pakistan in Washington) puts it this way: "Many people here feel that Pakistan and the U.S. cannot be strategic partners, that this is only a marriage of convenience. They are in the same bed but they have different dreams."(Pamela Constable, 2010). 


\section{References}

Adil Najam, Portrait of a Giving Community: Philanthropy by the Pakistani-American Diaspora (Harvard University Press, 2006).

Afghanistan and Pakistan Regional Stabilization Strategy, Office of the Special Representative for Afghanistan and Pakistan (United States Department of State, Updated February 2010), p. 29. Online www.state.gov/documents/organization /135728.pdf.

"A New Strategy for Afghanistan and Pakistan," The White House Blog (March 27, 2009). Online http://www.whitehouse.gov/blog/09/03/27/a-new-strategy-for-afghanistan-and-pakistan/.

Ann Weaver, Mary Pakistan: Deep inside the World's Most Frightening State (Farrar, Straus and Giroux, New York: Revised Edition 2010). See preface to this recent revised paperback edition.

Charles Krauthammer, "Terror and candor in describing the Islamist ideology behind it," The Washington Post (July 2, 2010). Online http://www.washingtonpost. com/wp dyn/content/article/ 2010/07/01/AR2010070104542.html.Frederick Kempe, Foreward to Pakistan in the Danger Zone, op. cit.

Fareed Zakaria, "A Victory for Obama: From an Unlikely Quarter - Pakistan," Newsweek (March 12, 2010). Online http://www.newsweek.com/2010/03/11/a-victory-for-obama.html. Also among others Spencer Ackerman, "The Obama Doctrine, Revisited," The American Prospect (April 7, 2010) online at http://www.prospect.org/cs/articles?article=the_obama _doctrine_revisited. Taking direct issue with Zakaria is Peter Feaver, "What Fareed Zakaria gets right - and wrong - on Obama's Pakistan policy," Shadow Government online at Foreign Policy (March 15, 2010) at http://shadow.foreignpolicy.com /posts/2010/03/15/ what_areed_zakaria_gets_right and\%20 wrong_on_obama_s_pakistan_policy. Feaver points out that most of what Zakaria attributes to Obama was already policy under George W. Bush.

Greg Miller, "Options studied for a possible Pakistan strike," The Washington Post (May 29, 2010). Available at http://www.washingtonpost.com/wp dyn/content/article/2010/05 /28/AR 2010052804854.html?hpid=topnews\&sid=ST2010052801870.

"ISI accused of funding, training Afghan Taliban," Dawn (June 14, 2010) p.1. Dawn was quoting from the Waldmann report.

Jayshree Bajora, "Obama's Pakistan Challenge," Analysis Brief (Council on Foreign Relations, January 2, 2009). Online http://www.cfr.org/publication/18114 obamas_pakistan_challenge.html.

Jane Perlez, Eric Schmitt and Carlotta Gall, "Pakistan is Said to Pursue a Foothold in Afghanistan," The New York Times (June 24, 2010). Online http://www.nytimes.com/2010/06/25/world/asia/25islamabad.html. 
Jeremy Page and Zaid Hussain, "Barack Obama's Pakistan policy in disarray after opposition to $\$ 7.5 \mathrm{bn}$ aid conditions," The Times (October 14, 2009). Online http://www.timesonline.co.uk/tol/news/world/asia/article6873616.ece. See also the excellent discussion on Nawa, op. cit.

Karen DeYoung and Greg Jaffe, "U.S. 'secret war' expands globally as Special Operations forces take larger role," The Washington Post,(Friday, June 4, 2010).Online http://www.washingtonpost.com/wp dyn/ content /article /2010/06/03 IAR2010060304965.html?hpid\%3Dtopnews\&sub=AR.

Kerry-Lugar letter available at http://www.boston.com /news/politics /politicalintelligence/0305 10\%20 JK\%20RL\%20to \%20Lew\% 20re\% 20Pakistan\%20FY\%2010.pdf.

Laura Rozen, "Obama's Pakistan Problem," Politico (October 8, 2009). Available at http://www.politico.com/blogs/laurarozen/1009/Obamas_Pakistan_problem.html.

Lisa Curtis, "Taliban Reconciliation: Obama Administration Must Be Clear and Firm," Backgrounder (The Heritage Foundation, March 11, 2010, no. 2384, p.4). Online www.heritage.org/Research/Asiaandthe Pacific/bg2384.cfm.

Mark Mazzetti, "U.S. Is Said to Expand Secret Actions in Mideast," The New York Times (May 24, 2010). Online www.nytimes.com/2010/05/25/world/25military.html.

Matt Waldmann, The Sun in the Sky: The Relationship between Pakistan's ISI and Afghan Insurgents, (Crisis States Discussion Papers, Crisis States Research Centre, June 2010). Online http://www.crisisstates.com/download/dp/DP\%2018.pdf. See also Matthew Rosenburg, "Arrests Force Taliban Flight," The Wall Street Journal (March 11, 2010). Online http://online.wsj.com/article/SB100014240527487 03701004575 113741711001292.html. For another skeptical view see Miles Amoore, "Pakistan puppet masters guide the Taliban killers," The Sunday Times (June 13, 2010). Online http://www.timesonline.co.u k/tol/news/world /afghanistan/article7149089.ece.

Amoore draws on the recent London School of Economics report by Matt Waldmann. For a list see of those killed and arrested see Katherine Tiedemann, "A guide to recent militant arrests and deaths in Afghanistan and Pakistan," Foreign Policy (March 8, 2010). Online http://afpak.foreignpolicy.com /posts/2010/03/08/a_guide_to_recent_ militant_arrests_and_deaths_in_afghanistan_and_pakistan.

Michael Hirsh, "Obama's Pakistan Successes," Newsweek Web Exclusive (Feb 23, 2010). Available at http://www.newsweek.com/id/234041.

Michael O'Hanlon and Ian S. Livingston, "Pakistani Index: Tracking Variables of Reonstruction \& Security in Pakistan," Brookings Institution, February 10, 2010, http://www.brookings.edu/foreign-policy/pakistan-index.aspx. "Report termed malicious," Dawn (June 14, 2010) p.1. 
Rajan Menon, "Pakistan's dual policy on Taliban," The Los Angeles Times (June 30, 2010). Online http://articles.latimes.com/2010/jun/30/opinion/la-oe-menon-afpak20100630. Rajan Menon is a professor of international relations at Lehigh University and of political science at City College of New York/City University of New York.

Shuja Nawa, Pakistan in the Danger Zone: A Tenuous U.S. - Pakistan Relationship (The Atlantic Council, June 2010), pp. 11-13. Online http://www.acus.org/publication /pakistan-danger-zone.

Shirin R. Tahir-Kheli, "Obama's Pakistan Problem," The Daily Beast (October 23, 2009), online http://www.thedailybeast.com/blogs-and-stories/2009-10-23/obamas-pakistanproblem/.

The Times, The News, Dawn, and The Nation. All on June 14, 2010.

Scott Shane, "Pakistan's Plan on Afghan Peace Leaves U.S. Wary," The New York Times (June 27, 2010). Online http://www.nytimes.com/2010/06/28/world/asia /28taliban.html?ref=scott_shane.

K. Alan Kronstadt, Pakistan-U.S. Relations (Congressional Research Service: CRS Report for Congress, February 6, 2009), p.94. See in the same report the section "U.S. Aid and Congressional Action," pp. 84-94. Available online http://www.fas.org/sgp/crs/row/RL33498.pdf.

"Musharraf admits US aid diverted," BBC News (September 14, 2009). Online http://news.bbc.co.uk/2/hi/south_asia/8254360.stm.

National Security Strategy of the United States 2010. Available online at http://www.whitehouse.gov/sites/default/files/rss_viewer/national_security_strategy.pdf.

"Obama: U.S. prepared to pursue targets in Pakistan," CNN politics.com, March 29, 2009. Available online http://edition.cnn.com/2009/POLITICS/03/29/obama. pakistan/index.html.

"Remarks by the President in Address to the Nation on the Way Forward in Afghanistan and Pakistan," http://www.whitehouse.gov/the-press-office/remarks-president-addressnation-way-forward-afghanistan-and-pakistan. "Meet the Press" transcript at December7, 2008, http://www.msnbc.msn.com/id/28097635.

Pakistan's Nuclear Weapons: Proliferation and Security Issues, Paul K. Kerr and Mary Beth Nikitin, Congressional Research Service (February 23, 2010). Available at http://www.fas.org/sgp/crs/nuke/RL34248.pdf.

"Remarks on Nuclear Non-proliferation at the University of Louisville as Part of the McConnell Center's Spring Lecture Series," (April 9, 2010). Available at U.S. Department of State: Diplomacy in Action, http://www.state.gov/secretary/rm/2010/04/139958.htm.

Journal of Independent Studies and Research - MSSE

Volume 9

Number 1

January 2011 63 
"US studying China-Pakistan nuclear deal," Agence France Presse (May 11, 2010).

Obama mentions some of this in his autobiography Dreams from My Father. Stories of Obama's visit to Pakistan can be found all over the net. A good summary is at LaurenceJarvikOnline, http://laurencejarvikonline.blogspot.com /2010/05/presidentobamas-pakistan-connections.html; His remarks on his personal bond are quoted in Alan Fisher, "Obama's Pakistan dilemma," Aljazeera.net (January 19, 2010), online http://english.aljazeera.net /focus/2010/01/2010118114743559218.html.

Pew Global Attitudes Project http://pewglobal.org/2010/06/17/obama-more-popularabroad-than-at-home/. The full poll, 176 pages, is accessible from this site. Summary available at "Muslims, Americans down on Obama's foreign policy," (June 17, 2010), Foreign Policy at http://thecable.foreignpolicy.com /posts/2010/06/17/muslims_americans down_on_obama_s_foreign_policy. Anectdotal comments are found at Fisher op. cit.

Seth G. Jones and Martin C. Libicki, How Terrorist Groups End: Lessons for Countering al Qa'ida (Rand, 2008). Available online at http://www.rand.org /pubs/monographs/ 2008/RAND_MG741-1.pdf.

"Presidential hopefuls attack Obama's remarks about Pakistan," at CNN.com politics, August 8, 2007; http://edition.cnn.com /2007/POLITICS /08/07/obama.pakistan/index.html.

Tahir Andrabi, Jishnu Das, Asim ljaz Khwaja, and Tristan Zajonc, Religious School Enrollment in Pakistan: A Look at the Data," Comparative Education Review (August 2006, vol. 50, no. 3); K. Alan Kronstadt, Education Reform in Pakistan (CRS Report for Congress, December 2004), online at http://www.fas.org/man /crs/RS22009.pdf; and Riaz Ahmed Shaikh, "Developing Extremist-Madrasah Education in Pakistan" in D.M. Nault (ed.), Development in Asia- Interdisciplinary, Post-neoliberal, and Transnational Perspectives, (Brown Walker Press, 2008).

Sebastian Abbott, "US envoy cautions Pakistan over Iran gas deal," Associated Press (June 20, 2010). Also on same date "US cautions Pakistan over pipeline deal with Iran," Agence France Press.

Stephen E. Ambrose and Douglas G. Brinkley, Rise to Globalism: American Foreign Policy since 1938 (Penguin Books, 8th revised edition, 1997); or Stephen E. Ambrose, Eisenhower: Soldier and President (Simon \& Schuster, 1990).

Pamela Constable, "Pakistani Government, Military Wary of U.S. Overtures," The Washington Post, January 25, 2010, http://www.washingtonpost.com /wpyn/content/article /2010/01/24/AR2010012402890.html.

"US should be more even-handed in South Asia," Dawn (June 15, 2010). Online http://www.dawn.com/wps/wcm/connect/dawn-content-library/dawn/thenewspaper/local/us-should-be-more-evenhanded-in-south-asia-560. The reactions can be found in the Pakistani dailies of June 11, 12, and 13, 2010. For example "Kerry's warning," in The News (June 13, 2010), p. 7. 